\title{
Does COVID-19 Infection Affect Female Reproductive System?
}

\author{
Nevin Sağsöz $z^{*(1)}$
}

$\mathrm{S}$ tarting in December 2021, in the city of Wuhan, China, and spreading rapidly all over the world, SARS-CoV-2 (COVID-19) has led to an increase in morbidity and mortality all over the world. The most common findings are fever, sore throat, and myalgia. Although clinical findings can be mild sometimes, symptoms can be serious enough to cause death, such as severe acute respiratory syndrome (SARS) (1). One of the mechanisms held responsible for the multiorgan complications of COVID-19 is its entry into the cell via angiotensin converting enzyme-2 (ACE2) (2). The S protein of the virus binds to ACE2 receptor of the host cell, and this complex is exposed to proteolytic processing by the host type II transmembrane serine protease (TMPRSS-2) enzyme and the virus enters the cell (3). Therefore, tissues with high ACE2 receptors may be more sensitive to this virus. The presence of these receptors in ovarian granulosa cells has been demonstrated in previous animal studies (4). Moreover, the importance of ACE2 in human ovary has been shown $(5,6)$.

On the other hand, the uterus, especially endometrium, has pivotal role in fertility and, components of the reninangiotensin system (RAS) are found in epithelial and stromal cells of endometrium (7). Furthermore, viral entry is dependent on primary cleavage of the $S$ protein, which cleavage can be activated by one or more host proteases, including FURIN, trypsin, cathepsin, TMPRSS-2, or TMPRSS-4 (transmembrane serine protease 4) (3). In human endometrium, the expression of proteases such as TMPRSS4, CTSA (Cathepsin A), CTSB (Cathepsin B), CTSL (cathepsin L), BSG (basigin), FURIN, and MX1 has been shown to vary in different phases of the cycle in both natural and controlled ovarian stimulation cycles. It has also been found that this expression increases with age. For this reason, it has been stated that the endometrium and implantation may be affected by the virus more specifically with age $(8,9)$. Therefore, Covid-19 may affect endometrium and implantation (10).

In various studies, transient menstrual changes, usually in the form of prolonged cycles and reduced

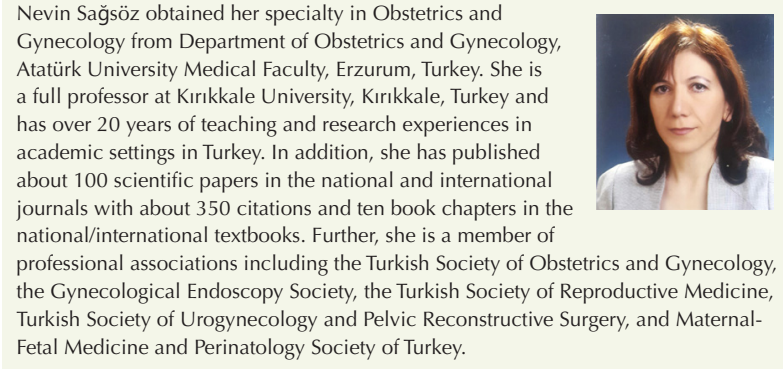

bleeding volume were observed in patients infected with COVID-19 (11-13). In a small group of patients, shorter or disordered menstrual cycles, and heavy menstrual bleeding were observed compared to the control group. Changes to menstruation did not vary with the severity of the disease and generally returned to normal within a few months of follow-up (12). Changes in anti-Mullerian hormone $(\mathrm{AMH})$ and the other hormone levels are currently unclear in the literature $(12,13)$.

All these menstrual changes may be due to the stress caused by the disease or the direct effects of the virus on the ovary and endometrium. This whole process may adversely affect fertility and ovarian reserve. However, current data are very limited and additional studies are needed.

\section{Ethical Issues}

Not applicable.

\section{Conflict of Interests}

The author has no conflicts of interest to disclose.

\section{References}

1. Umakanthan $\mathrm{S}$, Sahu $\mathrm{P}$, Ranade $\mathrm{AV}$, et al. Origin, transmission, diagnosis and management of coronavirus disease 2019 (COVID-19). Postgrad Med J. 2020;96(1142):753-758. doi:10.1136/postgradmedj-2020-138234

2. Zhang H, Li HB, Lyu JR, et al. Specific ACE2 expression in small intestinal enterocytes may cause gastrointestinal symptoms and injury after 2019-nCoV infection. Int J Infect Dis. 2020;96:19-24. doi:10.1016/j.ijid.2020.04.027

3. Ou X, Liu Y, Lei X, et al. Characterization of spike glycoprotein of 
SARS-CoV-2 on virus entry and its immune cross-reactivity with SARS-CoV. Nat Commun. 2020;11(1):1620. doi:10.1038/s41467020-15562-9

4. Tonellotto dos Santos J, Ferreira R, Gasperin BG, et al. Molecular characterization and regulation of the angiotensin-converting enzyme type 2/angiotensin-(1-7)/MAS receptor axis during the ovulation process in cattle. J Renin Angiotensin Aldosterone Syst. 2012;13(1):91-98. doi:10.1177/1470320311417273

5. Reis FM, Bouissou DR, Pereira VM, Camargos AF, dos Reis AM, Santos RA. Angiotensin-(1-7), its receptor Mas, and the angiotensinconverting enzyme type 2 are expressed in the human ovary. Fertil Steril. 2011;95(1):176-181. doi:10.1016/j.fertnstert.2010.06.060

6. Pan PP, Zhan QT, Le F, Zheng YM, Jin F. Angiotensin-converting enzymes play a dominant role in fertility. Int J Mol Sci. 2013;14(10):21071-21086. doi:10.3390/ijms141021071

7. Vaz-Silva J, Carneiro MM, Ferreira MC, et al. The vasoactive peptide angiotensin-(1-7), its receptor Mas and the angiotensin-converting enzyme type 2 are expressed in the human endometrium. Reprod Sci. 2009;16(3):247-256. doi:10.1177/1933719108327593

8. Henarejos-Castillo I, Sebastian-Leon P, Devesa-Peiro A, Pellicer A, Diaz-Gimeno P. SARS-CoV-2 infection risk assessment in the endometrium: viral infection-related gene expression across the menstrual cycle. Fertil Steril. 2020;114(2):223-232. doi:10.1016/j. fertnstert.2020.06.026

9. Haouzi D, Entezami F, Tuaillon E, et al. SARS-CoV-2 and implantation window: gene expression mapping of human endometrium and preimplantation embryo. Life (Basel). 2021;11(12):1378. doi:10.3390/life11121378

10. Kurdoğlu Z. Do the COVID-19 vaccines cause menstrual irregularities? Int J Womens Health Reprod Sci. 2021;9(3):158159. doi:10.15296/ijwhr.2021.29

11. Ozimek N, Velez K, Anvari H, Butler L, Goldman KN, Woitowich NC. Impact of stress on menstrual cyclicity during the COVID-19 pandemic: a survey study. J Womens Health (Larchmt). 2021;31(1):84-90. doi:10.1089/jwh.2021.0158

12. Li K, Chen G, Hou H, et al. Analysis of sex hormones and menstruation in COVID-19 women of child-bearing age. Reprod Biomed Online. 2021;42(1):260-267. doi:10.1016/j. rbmo.2020.09.020

13. Ding T, Wang T, Zhang J, et al. Analysis of ovarian injury associated with COVID-19 disease in reproductive-aged women in Wuhan, China: an observational study. Front Med (Lausanne) 2021:8:635255. doi:10.3389/fmed.2021.635255

(C) 2022 The Author(s); This is an open-access article distributed under the terms of the Creative Commons Attribution License (http:// creativecommons.org/licenses/by/4.0), which permits unrestricted use, distribution, and reproduction in any medium, provided the original work is properly cited. 